\title{
MADHOUSE OR PRISONERS HOUSE? NURSING IN JUDICIAL ASYLUM ${ }^{1}$
}

\author{
Dayane de Aguiar Cicolella², Maria Henriqueta Luce Kruse
}

${ }^{1}$ Text extraded from thesis - Between crime and madness: nursing in a forensic psychiatric hospital, presented the Programa de Pós-Graduação em Enfermagem, Universidade Federal do Rio Grande do Sul (UFRGS), in 2014.

${ }^{2}$ M.Sc. in Nursing. Universidade Federal do Rio Grande do Sul. Porto Alegre, Rio Grande do Sul, Brasil. E-mail: dayane.cicolella@ gmail.com

3 Ph.D. in Education. Professor, School of Nursing, the Programa de Pós-Graduação em Enfermagem, UFRGS. Porto Alegre, Rio Grande do Sul, Brasil. E-mail: kruse@uol.com.br

\begin{abstract}
The forensic psychiatric hospitals have objective to safeguard and treat mental patients, with a fusion between hospital and prison. Use techniques and disciplinary procedures normalizing criminally insane. The research studies the disciplinary measures used by nursing professionals working at Instituto Psiquiátrico Forense, Porto Alegre, Brazil. The theoretical framework lies in the field of cultural studies, post-structuralist strand, inspired by Michael Foucault notions. Ethnographic reswearch instruments were used: interviews recorded in audio, observation, analysis of documents and images. The results were organized in units: Madhouse or house of prisoners?; The organization of spaces and The control of time. In this institution, nursing carries the prison system heritage, manifested in daily routines. The way of caring, naturalized over time, produces professionals who repeat teachings of jailers, "transforming" patients in what is a normative proposal of the institution: organize it and readjust it according to rules of social life.
\end{abstract}

DESCRIPTORS: Forensic nursing. Mentally ill people. Criminals. Prisons.

\section{CASA DE LOUCOS OU CASA DE PRESOS? A ENFERMAGEM EM MANICÔMIO JUDICIÁRIO}

\begin{abstract}
RESUMO: Os manicômios judiciários possuem objetivo de custodiar e tratar doentes mentais, sendo uma fusão entre hospital e presídio. Utilizam técnicas e procedimentos disciplinares normalizando loucos criminosos. A pesquisa estuda os dispositivos disciplinares utilizados por profissionais da enfermagem que atuam no Instituto Psiquiátrico Forense, Porto Alegre, Brasil. O referencial teórico situa-se no campo dos estudos culturais, vertente pós-estruturalista, inspirado em noções de Michael Foucault. Foram utilizados instrumentos de investigação etnográfica: entrevistas gravadas em áudio, observação, análise de documentos e imagens fotográficas. Os resultados foram organizados em unidades: Casa de loucos ou casa de presos?; A organização dos espaços e O controle do tempo. Nesta instituição, a enfermagem carrega heranças do sistema carcerário, manifestadas em rotinas diárias. O modo de cuidar, naturalizado ao longo do tempo, produz profissionais que repetem ensinamentos de carcereiros, "transformando" os pacientes naquilo que é a proposta normalizadora da instituição: organizálo e reajustá-lo segundo regras de convívio social.
\end{abstract}

DESCRITORES: Enfermagem forense. Pessoas mentalmente doentes. Criminosos. Prisões.

\section{¿CASA DE LOCOS O CASA DE PRESOS? LA ENFERMERÍA EN EL MANICOMIO JUDICIAL}

RESUMEN: Los hospitales psiquiátricos judiciales tienen el objetivo de custodiar y tratar pacientes mentales, siendo una fusión entre el hospital y la cárcel. Ellos utilizan técnicas y procedimientos para normalizar criminales dementes. Esta investigación estudió las medidas utilizadas por los profesionales de enfermería que trabajan en el Instituto Psiquiátrico Forense, Porto Alegre, Brazil. El marco teórico se encuentra situado en el campo de los estudios culturales, inspirado por las ideas de Michael Foucault. Se utilizaron instrumentos de investigación etnográfica: entrevistas en audio, observación, análisis de documentos e imágenes. Los resultados fueron organizados en unidades: ¿Casas de locos o casa de presos?; La organización de los espacios y El control de tiempo. En esta institución, Enfermería carga las herencias del sistema penitenciario que se manifiestan en las rutinas diarias. La forma de cuidar, naturalizada con el tiempo, produce profesionales que repiten enseñanzas de carceleros, "convirtiendo" a los pacientes en aquello que es propuesto por la normativa de la institución: organizarlo y re-ajustarlo de acuerdo con normas sociales.

DESCRIPTORES: Enfermería forense. Enfermos mentales. Criminales. Prisiones. 


\section{INTRODUCTION}

The incessant search for control of the "abnormal" has been a concern of modern society. Subjects taken as insane and also those characterized as criminals draw attention because in our culture, the madman is someone who should be healed and the criminal punished for his actions. But what is there to do when there is an association between the need for healing with the idea of punishment? There is discussion here for the"insane criminal," one that moves between the world of madness and crime and enables the production of different discussions for its regulation.

Prisons and asylums arose in the Middle Ages as sites for the (re)socialization of individuals, recluses for a specified period of time, who would be able to live in social conviviality through the use of disciplining techniques. These establishments are included in the category of total institutions which are defined as a place where large numbers of individuals in similar situations separated from the wider society, for a considerable period of time, leading a closed and formally administrated life. ${ }^{1}$ These establishments operate under a detention regime, where a group of hospitalized persons are subjected to a smaller group. ${ }^{2}$

In the context of total institutions, judicial asylums integrate a combination of groupings among the institutions responsible for the care of the incapable and those destined for protection from everything social. They are constituted as institutions with a double objective, ie, custody and to treat dangerous mental disorders, being a mix of psychiatric hospital and prison. They receive people who meet security measures, and with types of sentence imposed when the subject commits an offense and does not have the full or partial capacity to understand the illicit nature of his act. ${ }^{3}$ However, if the foreseen fact as a crime is punishable by imprisonment, the judge may submit the person to outpatient treatment in the Psychosocial Care Center or Therapeutic Residences in the territory of their origin.

The judicial psychiatric asylums appeared to give attention and treatment to insane offenders which, because of dangerousness, could not remain in a psychiatric hospital due to the difficulty of controlling their behavior. In this sense, it was transformed into a healing and place of observation of mental illness, submitting bodies by disciplinary power. ${ }^{4}$ Discipline is a power exercise technique invented for managing people allowing detailed control of the body's operations, implying a docility-utility relationship through the fabrica- tions of submissive and trained bodies. ${ }^{4-5}$ It is part of a model considered great, and seeks to fit people into particular prototypes. ${ }^{6}$

The inclusion of nursing in judicial psychiatric asylums occurred from the nurses' experience in psychiatric hospitals, that through observation and patient control they used different techniques and disciplinary mechanisms. For many years, the asylums were exclusively organized and controlled by security professionals, and patient care was the exclusive task of people connected to the jail. However, only when the judges and doctors recognized and constituted the insane criminal as a sick person was when the profession earned its place in this system.

In the context of this story, the nursing professionals began to use different disciplinary measures for control and training of patients while concomitantly exercising care, with the important task of reintegrating them. Such measures included a set of actions, behaviors and philosophies for the purpose of treating/recovering patients and may be considered elements that define the history of the profession in asylums.

In this emergency scenario of insanity and crime, this study intends to reveal possibilities, understand processes and immerse in the working world of nursing professionals who work in judicial psychiatric asylums through the following question: what disciplinary measures are used by nursing professionals when caring for mental patients who fulfill judicial sentence in an inpatient regime under custody?

The aim was to analyze commentaries of nursing professionals who work in judicial asylums searching to understand what disciplinary mechanisms are used for patient care that meet safety measures.

\section{METHOD}

This is a qualitative research which approaches cultural studies and post-structuralist framework, using ethnographic research tools. It was developed in the Instituto Psiquiátrico Forense Doutor Maurício Cardoso (Forensec Psychiatric Institute - IPF), located in Porto Alegre-RS, Brazil.

Ethnography is characterized by a systematic process of observing, detailing, describing and analyzing lifestyles or specific patterns of a culture in order to learn their way of living and understanding meanings. ${ }^{7-8}$ In cultural studies, the methodological choices occur in accordance with the demands 
proposed by the research problem, without rigid disciplinary affiliation or even a methodological indication that is safe to answer the studied questions. ${ }^{9}$ In this respect, the study was inspired by the ideas developed by Michael Foucault in order to understand how the disciplinary measures used by nursing professionals in the care of these patients materialized.

A measure is constituted in a heterogeneous group that includes commentaries, institutions, organizations, regulatory decisions, laws, administrative measures,scientific statements, philosophical, moral and philanthropic propositions. In short, the said and the unsaid, the measure can be considered the network that can be woven between these elements. ${ }^{4}$ We understand how disciplinary nursing measures, all actions, conducts and philosophies proposals or determined by an intrinsic system which reproduces specific managements. So we do not use the term "discipline" with the negative impact which the word is known for and more, as a set of organizational practices that help professionals conduct their actions with patients.

The observation of practices developed by nurses, technicians and nursing assistants was possible through the experience with the teams during different shifts. Four months of immersion in the field (September to December 2013) paying attention to a very specific universe which was necessary to approach the work. For greater understanding of the context it was necessary to make use of observation techniques, interviews, analysis of documents and images proposed by ethnographic studies.

The institution operates with 27 nursing professionals, three nurses and 24 nursing technicians. 14 professionals were interviewed, using the strategy of selection of subjects known as the "snowball" type which is the intentional selection of the first interviewee, indicating the next subject and so forth ${ }^{10}$ The interviews were individual, recorded and then transcribed after the fact, and were arranged in a semi-structured way and guided by the question: how to be a nurse/nursing technician IPF? Respondents worked on all shifts and were given fictitious names personally chosen by themselves. This number had not been previously predetermined and occurred through the sample by theoretical saturation, a conceptual tool used to establish or close the final size of a sample by suspending the inclusion of new participants when redundancy or repetition of information was viewed. ${ }^{11}$

Participant observation allowed monitoring of the work routines of professionals and also under- standing of the legal and organizational processes in IPF. In participant observation the researcher remains within the group in that study, observes in a spontaneous way, as a spectator, although mobilizes information through their observations. ${ }^{12}$ For the development of this data collection method daily field records were used that enabled personal annotations with the commitment of anonymity to the subject and previous authorization of respondents and the institution.

The use of documents in research should be appreciated and valued. The wealth of information that they can retrieve justifies their use in various areas of knowledge because it allows the expansion of understanding of objects whose understanding requires historical and sociocultural context. ${ }^{13}$ In this sense, the document analysis allowed us to review the record books of all units of the IPF, extracting important annotations about the routines of professionals.

In response to the determinations of the Guidelines and Norms Regulating Research Involving Human Subjects, established by Resolution N. 466/12 of the National Health Council, this study was approved by the Etichal Research Committee of the Universidade Federal do Rio Grande do Sul, under protocol 398,834 in September 5, 2013 (CAAE 17245813.4.0000.5347).

\section{RESULTS AND DISCUSSION}

The results are presented in categories: Madhouse or prisoners home ?; The organization of spaces; and Time control.

\section{Madhouse or house of prisoners?}

Since its establishment the IPF carries the question: hospital or prison? In the early years of its construction it was linked to a health agency, however, due to political determinations, it was turned into an underlying security organ. Formerly referred to as "judicial asylum" it is between a prison and a psychiatric hospital, accommodating patients for indefinite times: it doesn't even come close to a hospital. It is a special house for custody and treatment. Somewhere between prison and hospital. It's kind of a halfway house for patients of the prison with mental illnesses. The judge determines the hospital and the patient comes here (Maria).

Unlike a regular prison, where there is a sentence to be served, the patient safety measure may be renewed by the doctors of the institution for as 
long as they consider necessary. ${ }^{14}$ The time is determined by the physicians who treated the patient and according to the evolution of this, they may request renewal of the security measure or judicial release. The patient's stay in the institution may be brief or occur for long periods of time, as mentioned by the interviewee: I always heard that in Brazil life imprisonment doesn't exist. Here in IPF and Brazil there is life imprisonment for the mentally ill. I saw many patients die here throughout the years (Lorena).

Regardless of whether it is a hospital or prison, some features and operating mechanisms include IPF in the field of "total institutions". "The total character that the institution acquires is due to the fact that it is a closed cell, for only one group of people, which are separated from the general society" ${ }^{15: 173}$ The separation of criminally insane from other members of society, their exclusion from the common insane group and other offenders determine their inclusion in this system. In this sense, the hospital asylum is organized as a therapeutic operator and a significant surveillance measure. In the context of disciplinary institutions, it includes the production of a microscopic control of machinery behavior of the thin and analytical divisions around men, i.e., an apparatus of observation, recording and training. ${ }^{5}$

Historically, the institution was created within a general asylum and, after a few years, became the responsibility of the Secretary of Security as "the asylums were not primarily designed to house, in general, any mentally ill or alienated persons who committed crimes" ${ }^{16: 27}$ Initially, it was coordinated and organized exclusively by guards, due to the absence of nursing professionals, correctional officers performed many tasks that would fit the nursing description, avoiding their true function: when I arrived here in 1990 the person who administered medications, who did all of this was the prison guard. So they were teaching me and telling me how it worked here (Lorena).

Through this report you can see that the work routines were imposed by the security team and with the arrival of the nurses, they were learning the ways of the agents and began to perform the actions permeated by this knowledge. This situation affected the professional identity of nursing, because after some time working together there was a mixture of roles which was felt as a disadvantage by all. ${ }^{17}$

Before the first civil service examination for hiring nursing staff, a professional category for the care of patients existed. These were called psychiatric assistants, people with a high school level education who held the dual role of caregiver and prison guard. Although the initial contract is specific to monitoring activity and the control of prisoners, these people had functions related to their professional training. "There were, yes, nursing professionals, such as monitors and correctional officers [...]. There were also nursing attendants, and civil servant psychiatric aides as correctional officers" ${ }^{17: 87}$

One respondent commented on the situation, after completing the civil service examination held for the high school level position, he had obtained the role of psychiatric aide in the institution. After a few years, he graduated from the technical course in nursing, funded by the state, becoming a member of the nursing staff. In an interview he said: when I started there, it was hand to hand approaching the patients to take care of them, And today is not like that, the treatment is quite different. Today I am Nursing technician, but when I started here I was a psychiatric aide. When we started, we learned psychiatric management, but nothing about nursing. There was only the prison guard and the psychiatric aide (Vera).

The insertion of nursing professionals allowed the profession to occupy spaces in the institution, However, these new roles were not easily accepted according to the reports: it was very difficult! We were all questioned all the time, we were pressured to constantly medicate the patients (Maria); [...] At the beginning when we started here, the prison guards were the people who did most of the help and the nursing technician services. They gave medications and they put the patient in mechanical restraint, They did everything. When we started, they thought that we came to pick on them (Mariana).

Despite internal conflicts and role confusion, it is noted that the experiences of the nursing in IPF is projected through the professional knowledge associated with the security team's knowledge. This fusion of knowledge and practices provides the nursing professionals who work in IPF with knowledge which the institution welcomes. The role of the profession in this place is unique and quite different from other areas. Nurses and technicians homogenize knowledge and practices related to the prison confinement.

\section{The organization of spaces}

The distribution of patients in space is one of the main disciplinary power characteristics..$^{18} \mathrm{In}$ IPF this classification is done by inpatient units in accordance with the disease, seriousness of the offense and gender. The division of patients by units 
allows for better control, observation and discipline because they have specific routines developed in accordance with the profile of the hospitalized patient. When the patient arrives they stay in the triage unit and, after medical evaluation and permission from the judge, they are sent to the closed units. If they are drug dicts they stay in Unit $G$ and if they are chronic, they stay in Unit $F$. The women go straight to the female unit (Field diary -Manu).

Discipline is a type of space organization. A distribution technique of individuals by inserting the bodies in an individualized space, combinatorial and qualifying. It isolates, probes, ranks and is able to perform different functions according to the specific purpose it requires. ${ }^{4}$ The organization of spaces, architectural layout, how individuals are distributed, how it flows and how it looks, or how it is looked at, this is what has therapeutic value. ${ }^{19}$

The constant monitoring of all patients is needed to control and for the organization of spaces. Forms of control and observation vary with inpatient units, but the nursing staff should be aware of the situation of patients because "exercising discipline theorizes a measure that requires the game of looking: a measure where the techniques allows us to see induced effects of power $[\ldots]^{\prime \prime}$. 5:165

Space control is an essential element of disciplinary technology, it ensures the distribution of individuals to be disciplined and supervised by facilitating the reduction of dangerous crowds. ${ }^{20}$ This space allows analysis and the combinatorial use of individuals as through disciplinary mechanisms, each individual has its place, and every place has its destination. ${ }^{21}$

In IPF the environments are organized in pavilions so that the patient is always in sight. The physical structure was formed maintaining a control area in the center where the chief of security and chief of nursing are located. This structure allows ongoing attention to any changes in the environment and seems to have architectural roots in the Panopticon Bentham prison type model.

Jeremy Bentham's design for an ideal prison was the paradigm to understand the disciplinary power and was characterized by spatial distribution, aiming at more detailed and accurate subjects, offering detailed and subtle tools to shape behaviours. ${ }^{22}$ There was a ring shaped construction located on the periphery and in the center there was a tower with large windows opening onto the inside of the ring. The peripheral construction was divided into cells, each occupying the entire width of the construction. The cells had two windows that opened to the in- terior and exterior, allowing the light to cross from one side to another. A watchman was placed in the central tower and in each cell a convict. Due to the effect of backlighting, small silhouettes of prisoners in the cells were oberserved. ${ }^{4}$

More important than observing was knowing if you were being observed. This proposed model that replaced the punishment and corporal punishment was intended to shape behavior through a relationship of power and knowledge about the body, consisting of control practices, rules and discipline. It was necessary that the prisoner was kept in sight permanently and it was necessary that all the notes about them were recorded and counted. ${ }^{5}$

The pavilion shape which forms the structure of the IPF contains the center control room of the main disciplining agents: the head of security and head of nursing. The units A, B, C, E (open units), F and $G$ (closed units) and the Admission and Triage unit together with the security area, are located in the peripheries. This pavilion system was preferred over the circular panopticon system due to providing equally high profile, where you can arrive without being heard by anyone while looking and capturing everything that is happening. ${ }^{19}$

\section{The control of time}

One of the main functions of the nursing team is patient control by administering daily medications at previously established times. The responsible physician prepares the prescription that is then transcribed by pharmacy staff. Transcription is carried out on pieces of cardboard, handwritten, and then placed in an envelope. This has the number and name of the patient. Medications are separated, so that they are in single doses, being deposited in each envelope. At each turn, employees are directed to the pharmacy to pick up the medication of patients under their responsibility. The medication comes from the pharmacy within an envelope. I look in the envelope and see if what is written is what is there. We do not work with direct prescription. We took the prescription when we were in doubt (Laura).

Although the employees knew it is important to check the medicine with the prescription prior to administration, this is not an established routine. They are based only on the transcription made by pharmacy staff who may be prone to errors. We observed that some professionals wouldn't even read what was written on the envelope and unpeel the medicines and deliver them to the hands of the patient 
Each unit has its specific routine for medication administration and for calling patients to receive the medication, it can be verbal or via a bell. In response, patients arranged themselves in rows to receive the prescribed medicine. This disciplinary routine individualizes bodies by a location that does not deploy them, but distributes and circulates in a network of relationships. The ranks organize the space and establish a distribution order. They are spaces that allow circulation, mark places and indicate values. This strategy ensures the obedience of individuals, better economy of time and management. ${ }^{5}$

It was observed that, regardless of ringing the bell, some patients were already waiting for the time to receive medication at the door of the nursing station, as reported: patients come in a row on their own. They are already used to it. They have a number on the packet. There is a box with medications. Each one has their own little package. They come and go saying their number. We check the number, we ask for the name, they say the name, we check the package and open the medication (Carolina).

The placement of patients in rows allows for greater organization of this procedure. Unlike a hospital, where the employee goes to the bedside of patients, the patient must go to the team. This practice works as a body disciplining mechanism because each must respect the time of the call, wait their turn in silence, with a water container in hand.

We noted that there is a "right way" to be patient in IPF. Who enters the institution is urged to be someone who understands and behaves according to the rules of the institution. By assuming the identity of a patient, they must accept agreements like keeping clean, bathing daily, answering the call bell, eating at certain times, smoking where it is allowed or even not smoking, coming and going according to the previous agreements and also sleeping or waking up in the stipulated time.

In all units, at the time of medication administration, most patients didn't usually say their name: primarily mentioning the number corresponding to their identification in the unit and after the registration name. Some say the number and the nickname, seeming not be familiar with their personal history. According to one respondent, this is not a pleasing situation: here I also saw the patient lose their identity when you start by calling the number. And he has a name! It's the same thing as you calling him by his nickname. The person is no longer a subject and becomes a number. One day, I was talking to a colleague, he said patient number seventy-something there in Unit C. Then I asked him if he knew his name, of course not [...]. The patient has a history, any number is just a number. They must be allowed to be a subject and have a history. Now the institution is trying to change that (Lorena).

Despite the institutional attempt to retrieve the individuality of the patient, not all employees strive to make this happen. The number is a reminder of the period in which the IPF which before the arrival of the nursing staff was entirely driven by correctional officers. The medication administration procedure at routine times was called "pay medication." Even after almost thirty years there are still remnants of this story: as soon as I start the shift we started "to pay the medication" and attend the demands of patients (Patricia).

In addition to medication schedules, patients also have schedules for confinement in closed units and closing the entrance doors in the open units. Generally, in the latter, the opening hours of the general gate is at 6 am and closing time is at $9 \mathrm{pm}$. Those responsible for this control are the nursing staff employees who take on the role of security guard for these functions. Our role here is also a little like a guard, opening and closing doors (Lorena).

This units closing process is called by the nursing "hitting padlocks" due to the sound produced by closing of the iron gates. Patients who have free access to the patio or IPF entrances and exits have a routine of gathering units at the mentioned times. They know that at such a time they should be in the units for closing time (Field diary - Manu).

Time keeping is an old legacy, created by the monastic communities which were found very early in schools, workshops and hospitals. The accuracy of your application are virtues of disciplinary proceedings. ${ }^{5}$

The closed units closing process occurs after the patient count of by security agents. The nursing staff is not involved in this task. According to the vast majority of respondents, this situation should occur in all units, whether they are closed or open. However, this does not occur often enough, remaining the duty of the nursing staff. We have many disagreements with the agents. They do not spend the night alone, they are not here with the patient. I open and close the door alone at five o' clock (Vera).

The responsibility of opening and closing the door for patients, controlling the unit and observing changes is not a pleasing feature for the nursing staff: there was no security officer in the unit at night and I was alone. In the morning, patients were asking me to open the door and so I opened it (Field diary - record in the occurrence book); [...] the unit conference was 
not performed by the correctional officers. I just closed the lock of the front door of the unit. Closing the side gate at 23 hours and remain on the unit without the prison guard accompanying me (Field diary - record in the occurrence book).

The nursing staff who work in treatment and custody hospitals explain that the characteristics of the place and the manner of treatment of hospitalized subjects are triggers for both positive and negative feelings based on experienced situations. ${ }^{23}$ The heir of hospice surveillance, owner of the permanent look and the space organizer are divided between the responsibilities of caring and guarding. ${ }^{24}$

Therefore, we observed that the importance is not to seek the changes that a particular object has suffered over a period of time in a given culture but what we see as natural, becomes problematic and historical and since many things that now seem natural are results of a series of contingent events. ${ }^{25-26}$

\section{FINAL CONSIDERATIONS}

Studying disciplinary behaviors performed by nurses, technicians and nursing assistants who work in psychiatric asylums make it possible to understand the emergence of the profession there. Understanding the Instituto Psiquiátrico Forense as a place that is between prison and mental hospital allowed us to understand the prison system legacies expressed by nursing professionals in their daily routines

Would it be possible to think differently in a universe that includes the madness within a broad system of restrictive and punitive measures produced by the prison unit? Having the prison official as "tutors" professionals learned to work in order to sort the spaces and control the bodies of patients. This way of working seems characteristic of professionals who work in prisons and differentiate from other places which have this profession. Thus caring, naturalized over time, produces nursing professionals who repeat the teachings of the prison guards without realizing the merging of the roles. The order and distribution of spaces are also the duty of the nurses. Responsible for the control of everything that happens in therapeutic units, workers spend most of their time organizing and training patients who circulate in the environment. It is an examination of time and space, where the body is controlled and handled by disciplinary techniques. Such inserted techniques, match and classify patients into spaces. It is therefore up to professionals to produce certain effects, transform- ing patients into what would be the normalizing proposal of the institution.

The insane person admitted to the Instituto Psiquiátrico Forense should be adjusted to the rules of social conviviality, and it is up to nursing professionals to provide its reorganization. The control of entrances and exits of the units, the way to dress and walk in the environment, how to sleep or eat, in short, every step must be accompanied by the profession in their daily task, recording the most alarming facts and informing the therapeutic staff.

Despite exercising diffuse roles in the judicial psychiatric asylums that mix incarceration functions with care, nursing professionals do not seem to be in agreement with the experienced situation and often do not try to associate themselves with the institution that is in possible decay. However, these professionals and all of us, reserve a question: what will the future of IPF be?

\section{REFERENCES}

1. Goffman E. Manicômios, prisões e conventos. São Paulo: Perspectiva; 1974.

2. Melo E, Renata R. Instituições totais, conceitos básicos. Análise institucional. 2008; [internet] [cited 2013 Set 30]. Available from: http:/ / analiseinstitucional.wordpress. com/2008/12/12/sobre-as-instituicoes-totais/

3. Brasil CS, Coelho ER, Brasil RS. Manicômio judiciário: pequeno ensaio sobre as forças que atuam nesse dispositivo. Cad Bras Saude Mental [internet]. 2009 [cited 2014 Fev 22]; 1(2):. Available from: http:/ / incubadora.periodicos.ufsc.br/index.php/cbsm/ article/view/1138/1377

4. Foucault M. Microfísica do poder. Rio de Janeiro: Graal; 2012.

5. Foucault M. Vigiar e punir: nascimento da prisão. Rio de Janeiro: Vozes; 2010.

6. Veiga-Neto A, Lopes M. Inclusão como dominação do outro pelo mesmo. São Paulo: In: Anais do VII Colóquio Internacional Michel Foucault; 2011 [cited 2014 Mar 23]. Available from: http://www. fe.unicamp.br/TEMPORARIOS/veiga-neto-lopesinclusao-como-dominacao.pdf

7. Hoga LA, Barbosa VA. Abordagem etnográfica. In: Matheus M, Fustinoni S, organizador. Pesquisa qualitativa em enfermagem. São Paulo: Livraria Médica Paulista; 2006. p. 53-60.

8. Thomé EGR. Homens doentes renais crônicos em hemodiálise: a vida que poucos vêem [tese]. Porto Alegre (RS): Universidade Federal do Rio Grande do Sul, Programa de Pós- Graduação em Enfermagem; 2011.

9. Sales SR. Etnografia+netnografia+análise de discurso: articulações metodológicas para pesquisar em 
educação. In: Meyer D, Paraíso M, organizador. Metodologias de pesquisa pós-críticas em educação. Belo Horizonte (MG): Mazza, 2012. p. 111-32.

10. Neves ACL, Miasso AI. Uma força que atrai: o significado das drogas para usuários de uma ilha de cabo verde. Rev Latino-Am Enfermagem. 2010; 18(Spe):589-97.

11. Fontanella BJB, Ricas J, Turato ER. Amostragem por saturação em pesquisas qualitativas em saúde: contribuições teóricas. Cad Saude Publica. 2008; 24(1):17-27.

12. Correia MCB. A observação participante enquanto técnica de investigação. Pensar Enfermagem [internet]. 2009 [cited 2012 Nov 2005]; 13(2): Available from: http:// pensarenfermagem.esel.pt/ files/2009_13_2_30-36.pdf

13. Sá-Silva J, Almeida CD, Guindani JF. Pesquisa documental: pistas teóricas e metodológicas. Rev Bras Hist Cienc Socias [internet]. 2009 [cited 2013 Mar 17]; 1(1):. Available from: https://www.rbhcs.com/ rbhcs/article/view/6/pdf

14. Fogliatto D. Vereadores de Porto Alegre visitam IPF e conhecem realidade de pacientes que cumprem medida de segurança. SUL 21 [internet]. 2014 [cited 2014 Abr 24]. Available from: http:/ / www.sul21.com. $\mathrm{br} /$ jornal/vereadores-de-porto-alegre-visitam-ipfe-conhecem-realidade-de-pacientes-que-cumpremmedida-de-seguranca/

15. Balan M, Furmann I. As instituições totais de Erving Goffman e a condição do encarcerado no sistema prisional: uma análise da visão dos interlocutores dos presos no Paraná. In: Gibran S, Tafuri J, organizador. Unicuritiba pesquisando o direito. Justiça e cidadania em debate. Curitiba (PR): Editora Clássica, 2013. p. 170-97.
16. Carrara SL. A história esquecida; os manicômios judiciários no Brasil. J. Hum. Growth Dev [internet]. 2010 [cited 2012 Out 22]; 20(1). Available from: http:/ / www. revistasusp.sibi.usp.br/pdf/rbcdh/v20n1/04.pdf

17. Langer LM. O papel do serviço de enfermagem no IPFMC. In: Souza C, Cardoso C, Cardoso R, organizador. Psiquiatria forense: 80 anos de prática institucional. Porto Alegre: Sulina, 2008. p. 87-95.

18. Sousa N, Meneses A. O poder disciplinar: uma leitura em Vigiar e Punir. Saberes [internet]. 2010 [cited 2014 Abr 06]; 1(4). Available from: http:/ / www.cchla.ufrn. br/saberes/

19. Foucault M. O poder psiquiátrico. São Paulo: Martins Fonseca; 2006.

20. Dreyfus H, Rabinow P. Michel Foucault: uma trajetória filosófica: para além do estruturalismo e da hermenêutica. Rio de Janeiro: Forense Universitária; 1995.

21. Fonseca MA. Michel Foucault e a constituição do sujeito. São Paulo: EDUC; 1995.

22. Oksala, J. Como ler Foucault. Rio de Janeiro: Zahar; 2011.

23. Stumm LK, Hildebrandt LM. Trabalhando com a loucura: a enfermagem no Instituto Psiquiátrico Forense. Rev. Contexto Saude. 2006; 6(11):37-46.

24. Miranda C. O parentesco imaginário. Rio de Janeiro: Editora da Universidade Federal do Rio de Janeiro; 1993.

25. Kruse MHL. Os poderes dos corpos frios: das coisas que ensinam às enfermeiras. Brasília (DF): ABEn; 2004.

26. Ribeiro RG, Kruse MHL. The woman body in review: the imperative of beauty. Texto Contexto Enferm [internet]. 2014 [cited 2014 Dez 10]; 23(1). Available from: http:/ / www.scielo.br/pdf/tce/v23n1/ pt_0104-0707-tce-23-01-00101.pdf 